\title{
The Contradiction between Media Ideology and Commodity Problems and Solutions
}

\author{
Zhang bing \\ The college of Marxism \\ Beijing Jiaotong University \\ No.3 Shang Yuan Cun, Hai Dian District Beijing, China Post-Code 100044 \\ 940758319@qq.com
}

\begin{abstract}
In the condition of the socialist market economy, the core issue of reform of the cultural system is to correct recognizing and grasping the relationship between ideology and commodity. The contradiction between ideology of network media and commercialization is objective. When we recognize this demonstrable fact, it is necessary to understand the contradiction and analyze the reasons between them. To solve the problem, it gets a great significance for the guidance and management of network media. It also makes a profound significance for completing the new situation of ideological propaganda. Meanwhile, it is propitious to reconcile with the socialism and market economy, and enhance the socialist market economy.
\end{abstract}

Keywords—network media; ideology; commodity

Under the background of drastic social changes, it's time to deepen an all-round reform in china. There are numerous contradictions and problems here. The main problem in the network media is the contradiction between ideology and commodity. The network media has the propaganda attribution of the CCP, and this attribution determines that the network medium should bear the propaganda of ideology. However, due to the impact of market factors, the network media has given up social benefits. So the propaganda and the leading role of the network media are reduced. In recent years, the social and economic benefits of the network media are gradually coordinated, there still is need to solve the contradiction between them.

\section{THE IMPACT OF THE COMMODITY PROPERTY OF NETWORK MEDIA ON THE IDEOLOGY}

\section{A. The political consciousness of network media is weak}

The media should be allowed to operate independently and to carry out its own entity operation in the process of establishing the socialist market economic system. The economic benefits, self-operate and commodity value of network media have been improved. Network media is no longer a simple commercial media. As the main tool of propaganda, it should undertake the propaganda of ideology. Therefore, it has the properties of both ideology and commodity. To enhance the economic efficiency, it has a great significance for the reputation of network media. Then it also has a profound significance for generating people's value pursuit. Meanwhile, these contents are conducive to the social ideological trend. However, some network media workers tend to pursue the one-sided pursuit of economic benefits that come with the competition of the market economy. Some network media workers regard the network media as a mean to pursue economic benefits which would be against their societal roles. Business interests and the value of commitment come first when they select news, which becomes the principal restraint on their internal or external pressure and the news production. They have no enthusiasm and sense of responsibility for participating in ideological work. In the opinion of some network media employees, the network media is a purely commercial media, ideological work should be in charge of the party propaganda department. They do not realize that the Internet media has a great influence on public opinion and plays an important role in the ideological struggle. This kind of speech makes the network media deviate from the humanist cultural creative thought. So they had some negative effects.

\section{B. The network media pays attention to the economic benefit unilaterally}

In September 2015, the general office of the CPC Central Committee and the general office of the State Council distribute <The guiding opinions on promoting the social benefits in the first place for state owned enterprises $>$. This file points out that the state cultural enterprises reform is not complete. Under the background of rapid development of cultural industry, the network medias are so closely linked with the capital that they abandon the independent artistic ability and production standards. And they also abandon the creative principles. Vulgar things replacing the lofty and bad money driving out the good have become a trend. Film and television drama about the anti-Japanese war which carries the collective memory of the people is important in culture, history and political implications not only in the present but also in the future. [1] But some anti-Japanese dramas have deviated from the fact of the China's Liberation War because economic benefits become the ultimate consideration. In order to improve the click-through rate, absurd stories are ceaseless being broadcast. These contents from the "torn devils" to the antiJapanese "yellow" not only lack historical accuracy, but also educational meaning. Similarly, in recent years, the time-travel TV series, and the Dynasty drama and so on that separate them from authenticity art are played by the media. " Where Are We 
Going, Dad 4", the program group focus on rendering Dong Li and Arale, the news media on the propaganda tweet, marketing account of the propaganda, unedited clips of the curtains onlookers. This cannot conceal the high risk of carnival, that posing a serious challenge to the authority of adults and the curiosity of children. Now our culture will develop into a farce. They have already broken the base line of spiritual culture.

\section{The disintegration of mainstream ideology}

The development of the network media industry is a double-edged sword. It can bring competition, innovation, diversity and vitality in many aspects. It also brings variety of ideas into all kinds of programs. "Most ideas are conducive to the promotion of economic development and improvement the liberation of ideas. Some ideas facilitate the crisis of moral degradation and some social problems." [2] In recent years, a variety of network programs not only pursue entertainment. They also allow money worship, hedonism, consumerism and other ideologies to prevail. Under this situation, mainstream ideology's role on leading cultural and social life is gradually digested. Market manipulates of some media and artists come to the stage which has ulterior motives to guide the people towards entertainment, utilitarian, secular and tearing. Thus they can continue to erode the mainstream ideological positions. Keep the controversial topic of public opinion under observation in recent years, which in order to protect their interests in the fierce market competition to discredit the image of the Communist Party. And ignoring the positive energy information, man-made social contradictions "public opinion war" constantly staged. Chai's "under the dome" has become the capital group's voice tube. She wants to seek their own interests and the development of space, and put the country and people's interests behind. "Zhao Wei and Dai Liren event" are also a typical representative. These contents contravene the basic morality. And they confuse the public to abandon the bottom line. Such people never worry about the future of the nation. Many of the network media not only lack the sense of responsibility to maintain the mainstream ideology, the integration of multiple values and social trends, they also lack guidance. When they confront anti-mainstream ideology which even stands by the opposite. The media who are loyal to the Communist Party is constantly being criticized and threatened in such a situation.

\section{The CAUSES OF THE CONTRADICTION BETWEEN IDEOLOGY AND COMMODITY IN NETWORK MEDIA}

\section{A. The weakening function of consumer culture is strengthened}

Profound changes have taken place in the economic structure and social structure; this situation will inevitably lead to changes of values. The rise of consumer culture has had a profound impact on the practice of network media. In turn, the role of network media has further promoted the popularization of consumer culture and the trend of marginalization of socialist culture. As some scholars have pointed out, "The rise of consumer culture has to some extent taken the place of fundamental interests of the socialist culture." [3] Clickthrough rates of oppression promote online programs to broadcast the luxury of the secular life. The value of life and the meaning of existence have not been taken into account by network media workers. They only care about the stimulation of the senses in order to ingratiate the audience, so as to realize the huge profits of the media industry. But the fact is, the audience gets joviality by anesthesia, thus avoiding the pressure in the real world. Under the influence of consumer culture, the network media to create batch after batch of vulgar culture to compromise the network of programs, "costume hot", "anti-war fever", "variety heat", "draft hot", etc. They all reflect the audience's consumer orientation. For the vulgar to please the audience, regardless of good and bad, ugly social atmosphere projected into the literary and artistic creation. So that the value of network media has repeatedly reduced. People's emotions, desires and instincts are controlled by business logic, and they have been developed as a commercial resource. Therefore, the content of production and broadcasting has weakened the role of network media in the mainstream ideology.

\section{B. The network media has insufficient self-reflection and critical consciousness}

The modern network media is based on the developed productive forces. For the restriction and restriction of productivity on human beings are weakening, the development of network media cannot provide the support and recognition of moral belief. Therefore, these factors lead to the weakening of media self-reflection, which directly affects the critical mechanism of network media. The media must respond the public's wishes, needs and perspectives in the supervision of the market competition. However, the network media excessively follows the logic of market competition to give people what they want. Nevertheless, they ignore criticism and reflection for them. The media workers have the wrong value orientation which leads to their own opinion that consumption is the personal happiness. This view of the mainstream of the network media ideology gradually decays. Jean Baudrillard once said, "Today to see the production and perfection, but demise of the people themselves."[4]

The network media over-reliance on the role of the free market, even under certain conditions, considers the market as a blind alien force to rule them. The influence of collectivism is gradually weakening on media institutions. The power of the media is becoming more and more concentrated on itself. Deregulation of News writing reduces the existence of effective information. The socialization trend of network technology is reflected in the advertising priority, and led to the trivial news. The extravagant of entertainment is flooded. All of these reflect that the critical consciousness of the media system which is the essential characteristics of reflection and questioning. At the same time, the lack of rational thinking and moral responsibility of media workers, news is produced in this or that kind of situation where such pressure are compromise, resulting in the audience's moral dilemma. Is it necessary to reflect on the attitude to China's network media in news reports? China's network media as a whole development model and business model is worth reflection?

\section{Government guidance and management mechanism is not perfect \\ "Propaganda ideological work is tantamount to consolidate the Marxist in the field of ideology. These have been the}


common ideological foundation for the unity of the whole Party and the whole nation.” [5] This means our network media have duality. This leads the government has agreed to supervise and regulate in these fields. Network is not only necessary to carry out the social benefit through the sociopolitical propaganda work, but also obtain the economic benefit of the management process. Therefore, the government should not only regulate the network media to achieve the public interest. At the same time, they require the network media to operate independently. These situations have resulted in the duality and dilemma of management process. Overall, the government is expected to be very strict in the implementation of the provisions, but the pursuit of economic interests makes some irregularities as one falls. The government's management of the network program is mainly based on rules and regulations, but lack of effective legal norms. Government regulation of network media is imperfect. Because of this reason, in order to more profitable interests, the "There are policies, there are countermeasures" things will be happened often. Lack of standardized procedures for the evaluation of the final outcome is difficult to safeguard the interests of the public. The lack of standard evaluation criteria is the ultimate cause of the content is difficult to protect the public interest. For violation of the program led to the lack of penalties for repeated acts of connivance. Government's guidance of ideology is low, and the way of guidance is not perfect and scientific, which leads to the deviation from the ideological propaganda work of the network media and the fall of the position. "People's Daily" comments "The Legend of Zhen Huan", is in the evaluation of contemporary society Chinese to some extent. If the government gives up on its responsibilities, then the network media may be offset.

\section{THE SOLVE OF THE CONTRADICTION BETWEEN IDEOLOGY AND COMMODITY IN NETWORK MEDIA}

\section{A. Strengthening the education of network media ideology function}

The mainstream media is an important link between our nation and people. This content has special political significance and value. Therefore, in the era of reform and development of the complex situation and the diversity of social ideology. The profound changes in the media pattern make the network media should re-examine themselves. We will be more determined by its position and attitude in a particular historical period. Then we can follow the faith "role of the responsibility". We must clearly realize that the ideological work is the central work which is the duty and responsibility of the network media. Therefore, we must pay attention to people's livelihood and social justice. These are the key to the spirit of the mainstream values. This will require the network media to adhere to the premise of Marxism as the guide. And then the mainstream ideology to penetrate into the common sense of the people to create the experience and face the actual situation reflected, enrich the people's spiritual world, enhance people's spiritual strength. Such as Disney animated film "crazy animal city" worthy of our reference, excellent and lovely role, all ages to deal with the topic, shallow does not feel deep etc. More importantly, it is efficient and entertaining in the efficient transmission of information. Entertainment and thought hold the depth of integration and make it full of energy.
Equality and trust are expected to give the network media to strong support. The difference between children and adults enables the network media to transmit positively. On the surface of the content is changing the efficiency of media workers. The domination of the audience and the market does not mean that the social benefits of abandon, concentrate on the economic benefits, at the same time a moment cannot relax and weaken the ideological work. Freedom has its rules. But rules exist in the heart. "Keep in mind the original intention, firm belief", that in order to provide more and better spiritual food for the people.

\section{B. Speed up the step of network media innovation}

In the new situation, the function of the network media ideology has not changed, but great changes have occurred in the environment. The audience and scope, propaganda and ideological work cannot be self-proclaimed. In the face of complex international and domestic environment, the different needs of the audience, the expansion of new media etc. If the concept of obsolete, ideological work will be reduced. Promote public opinion to guide innovation is to conduct propaganda and ideological work of the inherent requirements. The network media needs to carry on the further research to the audience's psychological characteristic and the acceptance habit in the present situation. And it also needs to effectively change the commanding heights, empty preaching and patterns, slogan propaganda. The word "Moisten things silently" are the way of propaganda ". So that the main theme of the society can enter the brain and heart. To build a new pattern of public opinion, speak a good story of China, the dissemination of effective voice in China. The creation of network programming to really attractive and appeal, with communication and the value of heritage. Real life for the artist provides a wealth of material, should strive to create a reflection of the spirit of the times. Realistic works, which include contemporary values and historical consciousness, enhance cultural affinity. These works enable more people to understand the ways and means of Chinese culture.

\section{The management of the Communist Party and the} government must strengthen and perfect the supervision

Practice proved that the network media ideology commodities and ideological contradictions cannot simply rely on the media system to solve their own strength, but also with the help of the Communist Party and government management intervention and supervision.

Communist Party committees and governments at all levels should consciously assume the political responsibility and leadership responsibility, to play its management activities in the mandatory and guiding force. To strengthen the network media asset management, personnel management, oriented management, adhere to the decision-making power of major issues, propaganda the task of final right, the allocation of assets control, the main leading cadres of the appointment, Ensure the network media to fulfill the social and cultural responsibility. The Party committee and the government should set up a governing body for the regulation of Internet media. On the one hand, the management institutions in accordance with the law to promote the unified management of assets. On the other hand, through the research on the effective 
management of the management department and the Propaganda Department, we can improve the management and working mechanism of the propaganda department.

Establish and improve the social and economic benefits of the unity of the evaluation mechanism. We must determine the social efficiency is the primary standard of evaluation, and the evaluation of social benefits should be quantified from "political orientation", "literary creation", "audience", "social influence", "internal system" and "team building". At the same time, we should set up a scientific and rational reflection of market acceptance of economic indicators. Moreover, we are not only firmly opposed to "the box office", "only the clickthrough rate", "the only capital appreciation", but also to ensure the implementation of social benefits requirements.

In order to play a guiding role, incentive and guarantee the cultural and economic policies. The office of the CPC Central Committee and the State Council issued the <on the promotion of state-owned cultural enterprises in putting social benefits first, guidance in order to achieve the unity of social and economic benefits $>$. The document to implement and improve the cultural and economic policies. In order to ensure the reasonable economic benefits of network media, it is necessary to achieve sustainable development. The network media should improve the social benefit of the network media by highlighting the construction of industrial projects. According to the general requirements of the reform of fiscal and taxation system to implement and improve the tax preferential policies of the network media industry. Resist the vulgar ethos by strengthening the supervision of the cultural market and crack down on illegal and criminal of regulation. Management departments should resolutely in accordance with the law to ban the program content oriented serious problems of network programming.

\section{Improve the quality of network media workers' Political Theory}

The network media workers in the guidance of public opinion and the construction of media culture are responsible for important responsibilities. Excellent political quality and good professional qualities are the most basic quality. As the forerunner of the propaganda position, the network media workers should be qualified goalkeepers in position of public opinion, should have the basic professional ethics, and constantly improve the ideological capacity. As one scholar said: "Network open courses of ideological and political theory ecological...improve the environmental quality of the ideological and political theory."[6] We must carry out the propaganda of ideological and cultural work of the important speech spirit. Strengthen the bottom line consciousness, to be strict management, put its remarks into the assessment system, and constantly solve the fundamental problem。 "For whom, who rely on and who I am". In the face of complex social phenomena, to withstand the storm test; to enhance the sense of responsibility. In the face of new situations, new problems should be able to appropriate as positive voice, confidence and enthusiasm propaganda and ideological work.

Network media workers should have good qualities in order to hold the correct guidance of public opinion. They must have an acuity observation when they confront the innovation and phenomenon. Then they will be good at discovering, digging, and thinking, creating and spreading. Media workers must keep their equanimity and faith with the confidence to Chinese cultural spirit. Then they can tell China stories well and occupy the peak of international opinion.

\section{SUMMARY}

Therefore, this paper examines the main manifestation of the ideological impact of the current network media commodity. It is pointed out that it is necessary to study the characteristics of the network media. In this way, we can realize the unification of economic benefits of social benefits of network media. In order to further improve and develop the Party's propaganda and ideological work in the new era.

\section{REFERENCES}

[1] Qin Zhixi. Perspective on media culture[M]. Wuhan University Press, 2010. pp221. (In Chinese)

[2] Chen Xianda. An important issue in the study of traditional culture[J]. Philosophical research,2010(2). (In Chinese)

[3] Wu Bo. A study on the social formation of new China[M]. Jiangsu People's Press, 2014. pp358. (In Chinese)

[4] Jean Baudrillard. The consumer society: myths and structures[M]. SAGE Publications, 1998.

[5] Xi Jinping. The sprite of the series of important speeches by General Secretary Xi Jinping[M]. Chinese People's Publishing House, 2014. pp88. (In Chinese)

[6] Zhao J, Marxism D O, University N N, et al. Ecological Teaching: Consideration of the Network Open Courses of Ideological and Political Theory[J]. Journal of Hebei Normal University for Nationalities, 2016. 